prevalence of human papillomavirus antigen in biopsies from women with cervical intraepithelial neoplasia. J Clin Pathol 1985;38:855-7.

6 Jenkins D, Tay SK, McCance DJ, Campion MJ, Clarkson PK, Singer A. Histological and immunocytochemical study of cervical intraepithelial neoplasia (CIN) with study of cervical intraepithelial neoplasia (CIN) with 1986;39:1177-80.

7 Banks L, Matlashewski G, Pim D, Churcher M, Roberts C, Crawford L. Expression of human papillomavirus type 6 and type 16 capsid proteins in bacteria and their antigenic characterisation. J Gen Virol 1987;68:3081-9.

8 Patel D, Shepherd PS, Naylor JA, McCance DJ. Reactivities of polyclonal and monoclonal antibodies raised to the major capsid protein of human papilloma virus type 16 . J Gen Virol 1989;70:69-77.

9 Cason J, Patel D, Naylor J, Shepherd PS, Best JM, McCance DJ. Identification of immunogenic regions of the major coat protein of human papillomavirus type 16 that contain type-restricted epitopes. J Gen Virol 1989;70:2973-87.

10 Kornstein MJ, Weber J, Luck JB, Massey GV, Strom S McWilliams NB. Epstein-Barr virus associated lymphoproliferative disorder. Arch Pathol Lab Med 1989; phoproliferat

11 Brigati DJ, Myerson D, Leary JJ, et al. Detection of vira genomes in cultured cells and paraffin-embedded tissue sectons using biotin-labelled hybridisation probes. Virology 1983;126:32-50.

12 Wolber RA, Lloyd RV. Cytomegalovirus detection by nonisotopic in situ DNA hybridisation and viral antigen immunostaining using a two colour technique. Hum Pathol 1988;19:736-41.

13 Roberts WH, Sneddon JM, Waldman J, Stephens RE. Cytomegalovirus infection of gastrointestinal endohelium demonstrated by simultaneous nucleic acid hybridisation and immunohistochemistry. Arch Pathol Lab Med 1989;113:461-4.
14 Van der Loos CM, Volkers HH, Rook R, Van den Berg FM, Houthoff H-J. Simultaneous application of in situ DNA hybridisation and immunohistochemistry on one tissue section. Histochem J 1989;21:279-84.

15 Mullink H, Walboomers JMM, Tadema TM, Jansen DJ, Meijer CJLM. Combined immuno- and nonradioactive hyeider Coctive hybridocy influence of fixation, enzyme pretreatment, and choice of chromogen on detection of antigen and

16 Jenson AB, Lim LY, Singer AE. Comparison of human papillomavirus type 1 serotyping by monoclonal antibodies with genotyping by in situ hybridisation of plantar warts. J Cutan Pathol 1989;16:54-9.

17 Cubie HA, Norval M. Detection of human papillomaviruse in paraffin wax sections with biotinylated synthetic oligonucleotide probes and immunogold staining. J Clin Pathol 1989;42:988-91.

18 Burns J, Graham AK, McGee JO'D. Non-isotopic detection of in situ nucleic acid in cervix: an updated protocol. J Clin Pathol 1988;41:897-9.

19 Burns J, Graham AK, Frank C, Fleming KA, Evans MF, McGee JO'D. Detection of low copy human papilloma virus DNA and mRNA in routine paraffin sections of cervix by non-isotopic in situ hybridisation. J Clin Pathol cervix by non-is
$1987 ; 40: 858-64$.

20 Herrington CS, Burns J, Graham AK, Evans MF, McGee JO'D. Interphase cytogenetics using biotin and digoxigenin labelled probes I: relative sensitivity of both reporters for detection of HPV 16 in CasKi cells. J Clin Patho 1989;42:592-600.

21 Jiwa NM, Raap AK, Van de Rijke FM, et al. Detection of cytomegalovirus antigens and DNA in tissues fixed in formaldehyde. J Clin Pathol 1989;42:749-54.

22 Dartmann K, Schwarz E, Gissmann L, zur Hausen H. The nuclcotide sequence and genome organization of human papilloma virus type 11. Virology 1986;151:124-30.

\section{Eponyms in pathology ...}

von STERNBERG, Karl (1872-1935) was an Austrian pathologist, born and trained in Vienna, who qualified in 1896 . After working as assistant to Paltauf in Vienna he was made professor of pathology there in 1908. He described the characteristic giant cells of Hodgkin's disease in 1898, later described by Dorothy Reed (a pathologist at Johns Hopkins University, Baltimore) in 1906 . He also wrote a paper on "lymphosarcoma-cell" leukaemia, sometimes called Sternberg's leukosarcoma.

GIARD, Alfred (1846-1908) was a Parisian biologist who was a staunch follower of the doctrine of Lamarck. In 1882 he described the genus of flagellate protozoan now called Giardia.
PANETH, Joseph (1857-1890) was an Austrian physiologist, born in Vienna, who held chairs of physiology in Breslau and Vienna. In 1888 he described the secretory cells in the crypts of the small intestinal mucosa which now bear his name.

BETZ, Vladimir Aleksandrovich (18341894) was a Russian anatomist who was professor of anatomy in Kiev from 1868 to 1889 . He described the large pyramidal cells of the motor cortex (Betz cells) in 1874. 